\title{
Program Dakwah 'Serambi Islami' di TVRI Perspektif Audience And Users
}

\author{
Abdul Jalil \\ Widyaiswara Pusdiklat Tenaga Teknis Pendidikan dan Keagamaan, \\ Kementerian Agama RI, Indonesia \\ email: abduljalil.ruby@gmail.com
}

\begin{abstract}
The purpose of this study is to find out how the "Serambi Islami" da'wah program on TVRI is from the perspective of the audience and users? The author chose TVRI, because of its existence as the oldest state-owned television with a mission to provide information, provide entertainment, and facilitate education for the community. The theory used in this study is from audience to users proposed by Gill Branston and Roy Stafford. This research is a field study using a descriptive method and a qualitative approach. Serambi Islami is a religious program on TVRI that airs from 04.30 to 06.00 , every day from Monday to Sunday. This program is intended for all people who want to watch propaganda shows. To convey the messages of da'wah, an effective media is needed. Television is a strategic mass media as a means of da'wah. This media is very popular in the community that can reach audiences and users to remote areas. Presentation of da'wah materials on television that are weighty and attractive is an important part, so that viewers are interested in as objects of da'wah (mad'u).
\end{abstract}

\section{Keywords:}

Dakwah Program, Serambi Islami, Mad'u, Audience and User Theory

\begin{abstract}
Abstrak
Tujuan penelitian ini adalah untuk mengetahui bagaimana program dakwah "Serambi Islami" di TVRI dalam perspektif audience dan users? Penulis memilih TVRI, karena eksistensinya sebagai televisi tertua milik negara yang mengemban misi untuk memberikan informasi, menyajikan hiburan, dan memfasilitasi pendidikan bagi masyarakat. Teori yang digunakan dalam kajian ini adalah from audience to users yang dikemukakan oleh Gill Branston dan Roy Stafford. Penelitian ini adalah studi lapangan (field research) dengan menggunakan metode deskripsi dan pendekatan kualitatif. Serambi Islami adalah sebuah program keagamaan di TVRI yang tayang pada pukul 04.30-06.00, setiap hari dari Senin hingga Minggu. Program ini ditujukan
\end{abstract}


untuk semua kalangan yang ingin menyaksikan tayangan dakwah. Untuk menyampaikan pesan-pesan dakwah, diperlukan media yang efektif. Televisi merupakan media massa yang strategis sebagai sarana dakwah. Media ini sangat populer di tengah masyarakat yang dapat menjangkau audiens dan pengguna hingga ke pelosok. Penyajian materi-materi dakwah di televisi yang berbobot dan menarik menjadi bagian penting, sehingga diminati pemirsa sebagai objek dakwah (mad'u).

\section{Kata Kunci:}

Program Dakwah, Serambi Islami, Mad'u, Teori Audience and User

\section{Pendahuluan}

Dewasa ini, televisi merupakan media massa yang sangat populer di tengah masyarakat. Ia ada hampir di setiap tempat-tempat publik, kantor, rumah, bahkan kamar. Setiap informasi yang disampaikan melalui televisi, akan sangat mudah sampai ke tengah kalangan masyarakat. Demikian pula pesan-pesan tabligh, akan tersosialisasikan dengan cepat jika disampaikan melalui televisi. ${ }^{1}$ Karena itu, keberadaan televisi bersifat netral, tergantung siapa penggunanya. Ibarat pisau, dapat digunakan untuk kebaikan, misalnya memotong buah dan sayur, atau untuk keburukan, seperti membunuh. Televisi dapat menjadi alat untuk tujuan merusak akhlak bangsa, atau kebalikannya sebagai media dakwah, yakni mengubah kondisi yang buruk menjadi baik, dan yang sudah baik menjadi lebih baik.

Andi Faisal Bakti mendefinisikan, dakwah adalah usaha meyakinkan manusia untuk bertingkah laku sesuai dengan ajaran Islam berdasarkan batas pengertian mereka masing-masing. Dalam Islam, agar dakwah atau tabligh efektif, harus disertai dengan perbuatan yang mencakup proses menentukan tujuan atau niat, menyampaikannya dengan perkataan dan mengikutsertakannya dengan pekerjaan nyata. $^{2}$

${ }^{1}$ Aep Kusnawan, “Tabligh Melalui Televisi,” dalam Aep Kusnawan, et.al., Komunikasi Penyiaran Islam, (Bandung: Benang Merah Press, 2004), Cet. ke-1, h. 73-74.

2 Andi Faisal Bakti, Communications and Family Planning in Islam in Indonesia: South SulawesiMuslim Perceptions of a Global Development Program, (Leiden-Jakarta: INIS, 2004), h. 83. 
Nielsen Television Audience Measurement (TAM) di Indonesia menyatakan, pandemi covid-19 telah menyebabkan terjadinya perubahan perilaku konsumen, termasuk dalam hal mengonsumsi media. Hasil pantauan Nielsen TAM di 11 kota menunjukkan rata-rata kepemirsaan televisi meningkat, dari rata-rata rating $12 \%$ di tanggal 11 Maret 2020 menjadi 13,8\% di tanggal 18 Maret. Ini setara dengan penambahan sekitar 1 juta pemirsa televisi. Durasi menonton televisi pun mengalami lonjakan lebih dari 40 menit, dari rata-rata 4 jam 48 menit di tanggal 11 Maret menjadi 5 jam 29 menit di tanggal 18 Maret. Penonton dari kelas atas (upper class) menunjukkan kecenderungan lebih lama menonton televisi sejak 14 Maret, dan jumlahnya juga terus meningkat. Peningkatan ini terlihat dari rata-rata rating 11,2\% di tanggal 11 Maret menjadi $13,7 \%$ di tanggal 18 Maret. $^{3}$

Peningkatan juga terjadi di semua segmen umur, dengan yang tertinggi berada di segmen anak dan remaja (10-14 tahun). Direktur Eksekutif Nielsen, Hellen Katherina menambahkan bahwa dari 11 kota yang disurvei, menonton televisi menunjukkan tren kenaikan dengan peningkatan tertinggi terjadi di Jakarta sebesar 29\%, Yogyakarta 29\%, Palembang sebesar 38\%, dan Banjarmasin sebesar 20\%. Dalam hal kategori program, ada perubahan pola yang terjadi selama work from home (WFH) dan Ramadan. Pemirsa televisi menonton lebih banyak serial dan program berita sejak periode WFH. Sementara selama Ramadan, pemirsa televisi tidak hanya menonton lebih banyak serial, tetapi juga program hiburan, keagamaan, dan pendidikan. ${ }^{4}$

Tayangan televisi yang kontennya memuat hiburan dan iklan-iklan lebih dominan dibandingkan dengan pesan-pesan dakwah. Hal ini terjadi, karena tayangan hiburan dan iklan lebih menarik serta diminati oleh pemirsa televisi

${ }^{3}$ Dwi Tupani, “Nielsen: Covid 19 Tingkatkan Jumlah Penonton Televisi," 23 Maret 2020, https://mediaindonesia.com/humaniora/298392/nielsen-covid-19-tingkatkan-jumlah-penontontelevisi, diakses 30 November 2020.

${ }^{4}$ Boyke P. Siregar, "Jumlah Penonton Televisi Naik 12/\% Sejak Ada PSBB dan WFH," 13 Mei 2020, https://www.wartaekonomi.co.id/read285326/jumlah-penonton-televisi-naik-12-sejak-ada-psbbdan-wfh, diakses 30 November 2020. 
dibandingkan dengan ceramah para dai. Konsekuensinya, sekularisme dan budaya hedonis akan mereduksi nilai-nilai agama. Keberadaan televisi sebagai produk teknologi telah menjadi produsen kebudayaan yang berimplikasi terhadap perilaku masyarakat. Ketika sudah mulai banyak stasiun televisi yang non stop, berarti waktu kosong melihat televisi semakin mengecil. Kondisi seperti ini paradoks dengan ajaran Islam yang sangat menekankan urgensi waktu agar diisi dengan iman, amal saleh, dan saling mengingatkan dalam kebenaran serta kesabaran. $^{5}$

Dengan kecanggihan dan dampak televisi pada setiap orang yang menontonnya, penggunaan televisi sebagai media dakwah sangat efektif dilakukan. Televisi mampu menawarkan suatu bentuk kerangka dan ekspresi kultural yang khas secara teknologi dan institusional seperti ekspresi dari kekuatan-kekuatan sosial, politik dan ekonomi yang lebih luas. Sebagai media audio visual (dengar pandang), televisi memiliki daya persuasif yang sangat tinggi, karena audience dapat melihat gambar hidup dan suara sekaligus. Bahkan suara dan gambar hidup itu dapat diterima oleh audience pada saat sebuah peristiwa tabligh atau khutbah yang sedang terjadi, melalui liputan secara langsung. Televisi memiliki daya jangkau (converage) yang sangat luas dalam menyebarluaskan pesan secara cepat dengan segala dampaknya dalam kehidupan individu dan masyarakat.

Dalam tulisan ini akan dikaji: "Program Dakwah Serambi Islami di TVRI." Penulis memilih TVRI, karena eksistensinya sebagai televisi tertua milik negara yang mengemban misi untuk memberikan informasi, menyajikan hiburan, dan memfasilitasi pendidikan bagi masyarakat. Penulis merumuskan pertanyaan mayor dan beberapa pertanyaan minor. Pertanyaan mayornya adalah bagaimana program dakwah "Serambi Islami" di TVRI dalam perspektif audience dan users? Sedangkan pertanyaan minornya: Apa efek program tersebut terhadap audience dan users? Apa

${ }^{5} \mathrm{QS}$ al-Ashr/103:1-3. 
saja manfaat program tersebut bagi audience dan users? Sejauh mana kepuasan audience dan users terhadap program tersebut?

\section{Kerangka Teoretis}

Teori yang digunakan dalam kajian ini adalah from audience to users yang dikemukakan oleh Gill Branston dan Roy Stafford. ${ }^{6}$ Audience telah lama menjadi istilah kunci untuk pendekatan studi media tentang tanggapan dan penggunaan media modern. Audience, yang berasal dari kata "pendengaran," sering diasumsikan sebagai massa yang diam ketika mendengarkan atau menyimak khotbah, pidato pada sebuah pertunjukan teater. Audience merupakan kumpulan penonton, pembaca, pendengar, dan pemirsa berdasarkan yang diterapkan pada seluruh penelitian tentang media. Fokusnya pada jumlah total orang yang dapat dijangkau oleh satuan isi media tertentu dan jumlah orang dalam karakteristik demografi tertentu. Cara membedakan massa dan bagaimana pengelompokan tanggapan mereka yang beragam, telah menjadi bagian dari kajian media. Fokus selanjutnya adalah berhenti mengatakan bahwa audience cenderung pasif, karena istilah audience menunjukkan banyaknya interaksi yang bervariasi yang mungkin terjadi dengan teks yang didistribusikan secara massal, seperti block buster film. Akan tetapi, beberapa bagian media seringkali tergelincir kepada asumsi bahwa seakan-akan pengguna (users) adalah massa yang dapat dibodohi dan ditipu. ${ }^{7}$

Istilah penonton juga tidak memadai untuk orang-orang yang terlibat dengan media interaktif. Pengaruh penyebaran teks secara luas seperti iklan yang dikombinasikan dengan pemasaran dan undangan lainnya, tidak membuat pengguna percaya begitu saja terhadap apa yang ditawarkan. Artinya, iklan tunggal

\footnotetext{
${ }^{6}$ Gill Branston, Roy Stafford, The Media Students's Book, (London and New York: Routledge, 2010), h. 379-402.

${ }^{7}$ Gill Branston, Roy Stafford, The Media Students's Book, h. 379. 
bagian dari dorongan pemasaran yang besar, layak dipelajari sebagai teks, dan mungkin jauh lebih efektif dari pada satu tweet ${ }^{8}$ menentang iklan itu. ${ }^{9}$

Branston dan Stafford mengelompokkan khalayak (audience dan users) menjadi empat bidang utama. Pertama, market driven (dorongan pasar). Khalayak pada kelompok pertama ini, ditempatkan sebagai konsumen sebuah produk iklan yang dipantau sejauh mana perhatiannya terhadap iklan-iklan yang disuguhkan kepada mereka. Kedua, concern about morality and sex ' $n$ ' violence (kepedulian terhadap moralitas dan kekerasan seks). Secara sederhana, media memiliki kekuatan yang dapat merusak tatanan sosial yang dapat merugikan para pengguna di kalangan anak-anak muda dengan menyebarkan bukti-bukti berbasis laboratorium seputar posisi korban kekerasan. Ketiga, responses to technological developments (respons terhadap perkembangan teknologi). Ketika bioskop di tahun 1920-an dan TV di tahun 1950-an menjadi media baru, semua orang dari dewasa hingga anak-anak menggunakan media ini. Keempat, questions about culture, politics and identity (pertanyaan tentang budaya, politik, dan identitas). Berkaitan dengan peran media dalam membingkai pemahaman publik, dan juga cara-cara menggunakan media teks dan objek yang berkaitan dengan ciri khas (identitas dan budaya), serta kepuasan dan fantasi. ${ }^{10}$ Pendekatan yang menekankan tentang apa yang dilakukan media terhadap audience, kekuatannya terletak pada pesan (hypodermic model). Inilah yang disebut model efek dalam komunikasi massa atau media massa.

8 Twitter adalah layanan jejaring sosial dan mikroblog daring yang memungkinkan penggunanya untuk mengirim dan membaca pesan berbasis teks hingga 140 karakter akan tetapi pada tanggal 07 November 2017 bertambah hingga 280 karakter yang dikenal dengan sebutan kicauan (tweet). Twitter didirikan pada bulan Maret 2006 oleh Jack Dorsey, dan situs jejaring sosialnya diluncurkan pada bulan Juli. Sejak diluncurkan, twitter telah menjadi salah satu dari sepuluh situs yang paling sering dikunjungi di Internet, dan dijuluki dengan "pesan singkat dari Internet. Di twitter, pengguna yang tidak terdaftar hanya dapat membaca kicauan, sedangkan pengguna terdaftar dapat menulis kicauan melalui antarmuka situs web, pesan singkat (SMS), atau melalui berbagai aplikasi untuk perangkat seluler. https://id.wikipedia.org/wiki/Twitter, diakses 1 November 2020.

${ }^{9}$ Gill Branston, Roy Stafford, The Media Students's Book, h. 380.

${ }^{10}$ Gill Branston, Roy Stafford, The Media Students's Book, h. 381. 
Penelitian tentang audience terfokus pada tiga model, yaitu model efek, uses (kegunaan) dan gratification (kepuasaan).

\section{Efek (hipodermik)}

Model efek juga disebut model hipodermik. Teori ini menggunakan analogi dengan mengumpamakan media seperti jarum yang menyuntikkan pesan kepada khalayak. Teori ini berpendapat bahwa media begitu kuat, sehingga dapat langsung memengaruhi khalayak sesuai dengan cara yang dimaksudkan oleh pendesain pesan. Teori efek media menekankan bagaimana media berbuat sesuatu terhadap audience. Audience dianggap pasif, tersugesti, tercandu, dan dipengaruhi. Pemaknaan atas suatu pesan sangat dipengaruhi oleh media. Para peneliti di era awal perkembangan ilmu komunikasi ini berasumsi bahwa media memiliki kekuatan untuk memberitahu orang tentang apa yang harus dipikir dan bagaimana harus berperilaku. ${ }^{11}$

Dengan pengalaman fasisme, berteori tentang 'efek' media populer pada 'audience massa' dalam istilah budaya yang luas, pendekatan yang berbeda dikembangkan AS pada tahun 1950-an. Para peneliti khawatir dengan persepsi peningkatan dalam tindak kekerasan (tidak termasuk perang) yang dianggap sebagai konsekuensi yang mungkin dari kekerasan seperti yang direpresentasikan di televisi (kemudian menjadi media baru). Berbeda dengan mazhab Frankfurt, mereka tidak tertarik untuk menghubungkan ini dengan analisis kritis masyarakat kapitalis akhir. Mereka berfokus pada kekuatan televisi untuk melakukan sesuatu kepada orang atau lebih tepatnya, kepada orang lain. ${ }^{12}$

Kembali kepada kedudukan budaya massa, biasanya diidentikkan dengan Frankfurt School. Mazhab Frankfurt, dari tahun 1920-an dan seterusnya, berteori tentang kemungkinan efek media modern saat itu dalam menanggapi penggunaan radio dan film oleh fasisme Jerman untuk tujuan propaganda. Belakangan, di pengasingan dari Nazi Jerman, para ahli teori 'Frankfurt' ini

${ }^{11}$ Gill Branston, Roy Stafford, The Media Students's Book, h. 382.

${ }^{12}$ Gill Branston, Roy Stafford, The Media Students's Book, h. 383-384. 
mengeksplorasi kekuatan media AS, termasuk iklan dan beberapa bentuk hiburan. Anggotanya mengembangkan varian Marxisme yang dikenal sebagai teori kritis, kerangka interdisipliner yang menggabungkan Marxisme, Freudianisme, filsafat dan penelitian ekonomi. Teori ini menekankan kekuatan korporasi kapitalisme, hak milik dan mengontrol media, untuk membatasi dan mengontrol kehidupan budaya dengan cara yang belum pernah terjadi sebelumnya, menciptakan apa yang disebut 'budaya massa' dengan ketundukan tanpa ruang untuk inovasi atau orisinalitas. Ironisnya, terlepas dari landasan mereka dalam Marxisme, kelompok tersebut tidak menghasilkan ide-ide tentang pekerja dan audience yang aktif dan terlibat yang mungkin menentang kontrol tersebut, dan pada tahun 1950-an mereka meninggalkan model konflik kelas sebagai motor sejarah. Habermas, seorang tokoh yang bertahan hidup, mengingatkan pengaruh teorinya tentang 'ruang publik'. Sementara mazhab Frankfurt dan lainnya, berasal dari Eropa. ${ }^{13}$

\section{Uses and gratification}

Teori uses and gratification menjelaskan bahwa audience dapat menolak dan memilih pesan bahkan memiliki kekuatan memengaruhi media. Audience secara bebas memilih untuk terpuaskan dan butuh atau tidak, serta secara bebas memilih tertarik dengan produk media yang diberikan atau tidak. Audience direpresentasikan sebagai individu yang bebas untuk menolak atau menggunakan suatu media. Teori uses and gratification beranggapan bahwa audience dianggap sebagai audience yang aktif dan diarahkan oleh tujuan. Audience sangat bertanggung jawab dalam memilih media untuk memenuhi kebutuhan mereka sendiri. Dalam pandangan ini, media dianggap sebagai satu-satunya faktor yang mendukung bagaimana kebutuhan terpenuhi, dan audience dianggap sebagai perantara yang besar. Mereka tahu kebutuhan mereka dan bagaimana

${ }^{13}$ Gill Branston, Roy Stafford, The Media Students's Book, h. 383. 
memenuhi kebutuhan tersebut. Mereka lebih selektif dalam menerima pesanpesan media, serta selektif pula dalam memilih dan menggunakan media. ${ }^{14}$

Pada tahun 1950-an, pendekatan (user and gratification model) ini tampak seperti menghirup udara segar, melawan pesimisme yang mudah dan penekanan behavioris yang kasar pada efek bekerja. Para peneliti (seringkali memiliki dana yang cukup dan terkadang bekerja dengan pengiklan) mempertanyakan orangorang mengapa mereka menonton televisi. Mereka menyimpulkan bahwa 'tipe kepribadian' dalam audience memunculkan 'kebutuhan tertentu, beberapa di antaranya diarahkan ke media massa untuk kepuasan' (Morley, 1992). Kebutuhan ini dikelompokkan ke dalam kategori seperti kognitif (pembelajaran); afektif (kepuasan emosional); pelepasan ketegangan (relaksasi); integratif pribadi (bantuan untuk masalah identitas pribadi); integratif sosial (bantuan dengan masalah identitas sosial). Model tersebut tidak tertarik untuk mengkritik budaya massa kapitalis. Memang beberapa dari penganut ekstrim hampir menyangkal pengaruh apapun untuk media, dan tidak pernah mengeksplorasi konsep kritis seperti 'integrasi sosial'. Sama seperti metafora obat-obatan, kecanduan dan kepasifan mencirikan tradisi 'efek'. ${ }^{15}$

Gerbner dan Gross, mengemukakan bahwa semakin banyak anda menonton televisi, semakin besar kemungkinan anda memiliki sikap menakutkan terhadap dunia di luar rumah, jenis pengaruh yang berbeda, lebih terkait dengan pendekatan budaya. Pertanyaan semacam itu telah dihidupkan kembali barubaru ini seputar saran, antara lain, Michael Moore dan Naomi Klein, dan dari Adam Curtis, bahwa kita hidup dalam budaya ketakutan, yang sekarang sengaja dipicu oleh politisi secara berlebihan. membesar-besarkan kecemasan yang sah tentang 'teroris'. Beberapa bagian media tampaknya senang memiliki berita utama 'seksi' yang dapat digunakan untuk meningkatkan penjualan dan rating tayangan. Contoh mengenai audiens ini, dan banyak lainnya, sebagian diambil

${ }^{14}$ Gill Branston, Roy Stafford, The Media Students's Book, h. 382.

${ }^{15}$ Gill Branston, Roy Stafford, The Media Students's Book, h. 388-389. 
dari karya tahun 1970-an, di Pusat Studi Budaya Kontemporer (Centre for Contemporary Cultural Studies CCCS), Universitas Birmingham, di bawah Stuart Hall. Meskipun tidak secara tegas berbicara tentang audiens berfungsi, ini memungkinkan peculasi tekstual tentang 'audiens' untuk mengambil arah baru yang berharga. Ini menentang pendekatan seperti analisis konten yang terkadang mengasumsikan hubungan yang mudah diukur antara elemen teks ('tindakan kekerasan' dan 'respons' penonton). Ini juga menjauh dari gagasan tentang ideologi tunggal yang dominan yang diekspresikan, atau tidak, dalam teks. Sebaliknya, ia mengembangkan model perjuangan hegemonik Gramsci yang lebih kompleks. Model kekuatan media hegemonik Gramscian yang luas ini (yaitu kekuatan yang terus-menerus harus bekerja untuk mendapatkan persetujuan, bukan hanya dipaksakan dari atas). ${ }^{16}$

\section{Metode Penelitian}

Penelitian ini adalah studi lapangan (field research) dengan menggunakan metode deskripsi dan pendekatan kualitatif. Tempat pelaksanaan penelitian adalah kantor TVRI yang beralamat di Jl. Gerbang Pemuda Senayan No. 8, Jakarta 10270. Dalam penelitian ini, subjek penelitian adalah pimpinan program, narasumber, dan yang terlibat dalam pelaksanaan program dakwah "Serambi Islami" TVRI. Sedangkan objek penelitiannya adalah kegiatan program dakwah "Serambi Islami" TVRI.

Teknik pengumpulan data dilakukan dengan observasi dan wawancara. Pedoman wawancara disusun dengan acuan $5 \mathrm{w}+1 \mathrm{H}$ (What, Why, Where, When, Who, + How), yang terdiri dari pertanyaan terbuka, tertutup, semi terbuka, dengan bentuk piramida terbalik atau yang biasa disebut membuat pertanyaan dari umum ke khusus. Pertanyaan bersyarat pun diperlukan sesuai kebutuhan. Pertanyaan dapat

${ }^{16}$ Gill Branston, Roy Stafford, The Media Students's Book , h. 389-390 
berubah sesuai dengan kondisi di lapangan dengan tambahan improvisasi dari peneliti.

Wawancara adalah proses memperoleh keterangan untuk tujuan penelitian dengan cara tanya jawab sambil bertatap muka antara pewawancara dan informan atau orang yang diwawancarai, dengan atau tanpa menggunakan pedoman (guide) wawancara. ${ }^{17}$

Semua teknis analisis data kualitatif berkaitan erat dengan metode pengumpulan data, yaitu observasi dan wawancara ataupun focus group discussion. Analisis data yang digunakan dalam penelitian ini adalah logika induktif, yaitu menggunakan logika berpikir di mana silogisme dibangun berdasarkan pada hal-hal khusus atau data di lapangan dan bermuara pada kesimpulan-kesimpulan umum. ${ }^{18}$

\section{Pembahasan}

\section{Sekilas tentang TVRI}

Televisi Republik Indonesia (TVRI) merupakan pelopor industri pertelevisian di Indonesia. Didirikan pada tanggal 24 Agustus 1962, bertugas mengangkat citra bangsa melalui penyelenggaraan penyiaran peristiwa berskala internasional, guna mendorong kemajuan kehidupan masyarakat serta perekat sosial. Lembaga penyiaran ini menyandang nama negara dan mengandung arti, yaitu siaran yang ditujukan untuk kepentingan negara. TVRI tercipta karena adanya kehendak rakyat dan pemerintah Republik Indonesia. Media penyiaran ini merupakan sejarah bagi bangsa Indonesia dan merupakan batu loncatan besar bagi bangsa Indonesia untuk mewujudkan cita-cita nasional. Lahirnya TVRI ditandai pada

\footnotetext{
${ }_{17}$ M. Burhan Bungin, Penelitian Kualitatif, Komunikasi, ekonomi, kebijakan publik dan Ilmu Sosial lainnya. (Jakarta: Kencana, 2011), h. 111.

${ }_{18}$ M. Burhan Bungin, Penelitian Kualitatif, Komunikasi, ekonomi, kebijakan publik dan Ilmu Sosial lainnya, h. 147.
} 
ketetapan MPRS No. II/MPRS/1960, Pasal 18, dinyatakan pentingnya pembangunan siaran televisi untuk kepentingan pendidikan nasional. ${ }^{19}$

TVRI telah menjadi Lembaga penyiaran publik (LPP) yang jika mengacu kepada konsep Public Service Broadcasting (PSB) dikategorikan sebagai National Public Service Broadcasting, berarti sistem penyiaran yang dikontrol oleh publik melalui KPI, sedangkan pendanaan dan struktur administrasinya diatur oleh peraturan yang mengikat. Menurut UU No 32 tahun 2002 pasal 11 (1). Lembaga penyiaran publik adalah lembaga penyiaran yang berbentuk badan hukum yang didirikan oleh negara, bersifat independen, netral, tidak komersial, dan berfungsi memberikan layanan untuk kepentingan masyarakat. Berdasarkan peraturan ini TVRI berkewajiban memberikan independensi informasi, keberagaman program, menjangkau minoritas dan mendidik masyarakat melalui informasi. Kesemua faktor tersebut tentunya juga harus didukung oleh pendanaan yang memadai dan kualitas teknik produksi siaran. Selain itu, persaingan ketat dalam industri penyiaran membuat TVRI harus memacu kreativitas dan kualitas siaran agar mendapatkan kembali penontonnya.

Di Indonesia, terutama sejak awal dekade 1990-an, dunia pertelevisian ditandai dengan semakin berkembangnya televisi lokal. Kehadiran televisi lokal ini sekurang-kurangnya dapat menyentuh kebutuhan khalayak yang lebih dekat. Ia dapat mendekati massa sesuai warna kultural yang dianutnya. Program yang disajikan lebih mampu menyentuh watak sosiologis penontonnya. Dengan demikian, sejatinya televisi dapat memberikan pengaruh yang lebih besar. ${ }^{20}$ Perkembangan pertelevisian di Indonesia mengalami kemajuan setelah deregulasi pertelevisian sejak 24 Agustus 1990. Beberapa stasiun televisi swasta bermunculan mulai dari RCTI, SCTV, TPI, ANTV, disusul Indosiar 1994.

19 Dewi Karina Firiana, Sejarah TVRI, Laporan Kuliah Kerja Profesi, Fakultas Seni Rupa dan Desain Institut Seni Indonesia Surakarta, 2016, h. 9.

20 Asep Saeful Muhtadi, Komunikasi Dakwah: Teori, Pendekatan, dan Aplikasi, (Bandung: Simbiosa Rekatama Media, 2012), h. 88. 
Perkembangan tersebut lebih marak lagi setelah pelarangan monopoli tahun 1999..$^{21}$

Sejak kehadiran televisi-televisi swasta, tidak dapat dipungkiri bahwa khalayak telah tersegmentasi. Khalayak kini secara tidak sadar "tersetir" oleh acara-acara televisi swasta yang terlalu berisikan tayangan hiburan. Jadi tak heran bahwa kecenderungan yang terlihat acara-acara seperti infotainment, sinetron dan reality show memang lebih diminati dibandingkan acara-acara mendidik dan penuh informasi, sehingga tayangan mendidik distigmakan sebagai acara yang membosankan. ${ }^{22}$

\section{Program "Serambi Islami"}

"Serambi Islami" adalah salah satu program keagamaan yang masuk nominasi dari 7 kategori penerima "Anugerah Syi'ar Ramadhan 2017" dari Komisi Penyiaran Indonesia (KPI) Pusat dalam kategori talkshow. Acara yang digelar di Jakarta, pada tanggal 26 Juli 2017 tersebut menempatkan program "Serambi Islami" TVRI setara dengan 4 (empat) program talkshow keagamaann lain, yakni Syiar Ramadhan (Metro TV), Tafsir Al Misbah (Metro TV), Ramadhan Bersama Din Syamsudin (TVRI) dan Kalam Kajian Islami (RTV). Dewan juri “Anugerah Syi'ar Ramadhan 2017" berasal dari KPI Pusat dan Majelis Ulama Indonesia (MUI). ${ }^{23}$

Serambi Islami adalah sebuah program keagamaan di TVRI yang tayang pada pukul 04.30-06.00, setiap hari dari Senin hingga Minggu. Program ini ditujukan untuk semua kalangan yang ingin menyaksikan tayangan dakwah. Sebelumnya nama acara dakwah ini berganti-ganti, pada tahun 2006/2007

${ }^{21}$ M. Tata Taufik, Etika Komunikasi Islam, (Bandung: Pustaka Setia, 2012), h. 85.

22 Syakur, Ryan A. 2010. diakses 19 November 2012. http://media.kompasiana.com/mainstream- media/2010/07/30/keberadaan-tvri-sebagai-televisipublik-di-indonesia.

${ }^{23}$ https://kabar24.bisnis.com/read/20170724/79/674521/ini-nominasi-program-televisi-terbaikselama-ramadan-2017 
ditetapkan namanya menjadi "Serambi Islami". Acara yang diproduksi secara tunda (taping) ini, merupakan satu-satunya acara dakwah yang memiliki peminat cukup banyak dan mampu bertahan di tengah menjamurnya program siaran keagamaan dan dakwah. ${ }^{24}$

Narasumber program ini berasal dari berbagai kalangan, dari mulai akademisi, tokoh agama, pejabat hingga celebrity. Latar belakang narasumber yang beragam, dimaksudkan untuk menarik audience atau penonton dari berbagai kalangan dan agar penonton tidak mudah bosan menyaksikan acara tersebut. Para narasumber terdiri dari Narasumber utama dan narasumber tamu. Nama-nama narasumber acara 'Serambi Islami" antara lain: Dr. Mukhlis Hanafi, MA., Dr. Lutfi Fathullah, MA., Dr. Rubiyanah, MA., Agus Darmawan, Syekh Faturrahman, AA Hadi, Kemalsyah, Yati Priyati. Adapun hostnya adalah: Hilman fauzi, Hizbullah, Julia, dan Firi Widi Waluya. Produser: Neneng Rosiati, Erlina Asnan, Ni Kadek Suartini, Rita Hendri, Sri Handayani, Warsono (Wawancara dengan Neneng Rosiati, Produser Program “Serambi Islami” TVRI, Jakarta, 09 Desember, 2020).

\section{Efek Program Dakwah}

Seluruh studi yang berkaitan dengan media massa didasarkan pada asumsi bahwa media memiliki dampak, meskipun belum diperoleh kesepakatan yang jelas mengenai dampak tersebut, apakah bersifat langsung atau tidak langsung memberi pengaruh yang besar atau kecil. Secara esensial, media massa telah memberi pengaruh kepada manusia baik secara langsung maupun tidak langsung.

Menurut Mc Luhan, bentuk media saja memberi pengaruh kepada kita. Pengaruh yang ditimbulkan oleh sebuah medium bukan hanya terletak pada isi pesannya, melainkan pula dipengaruhi oleh jenis media komunikasi yang

${ }^{24}$ Wawancara dengan Neneng Rosiati, Produser Program "Serambi Islami" TVRI, Jakarta, 09 Desember, 2020. 
dipergunakan interpersonal, media cetak atau televisi. ${ }^{25}$ Saat ini kita hidup dalam sebuah lingkungan yang disebut Mc Luhan sebagai Global Village yang berarti bahwa dengan perantaraan media komunikasi modern, memungkinkan berjutajuta orang di seluruh dunia merasakan kedekatan antara satu dan yang lain dalam sebuah lingkaran. ${ }^{26}$

Dampak yang ditimbulkan oleh sebuah media massa tidak dapat terlepas dari fungsi media massa itu sendiri dalam masyarakat. Beberapa faktor yang menyebabkan seseorang tertarik untuk bersentuhan dengan media massa di antaranya seperti yang dikemukakan McQuail. ${ }^{27}$ Pertama, fungsi informasi (information), yaitu menyediakan informasi tentang suatu peristiwa dan kondisi dalam kehidupan masyarakat dan dunia. Fungsi ini juga memberikan fasilitas terhadap adanya inovasi, adaptasi, dan kemajuan. Kedua, fungsi korelasi (correlation), yaitu menjelaskan, menginterpretasikan, dan mengomentari peristiwa dan informasi yang ada serta merupakan wadah dari proses sosialisasi dan membangun konsensus. Ketiga, fungsi kesinambungan (contuinitas), yaitu mengekspresikan budaya dominan dan mengakui kehadiran budaya baru. Keempat, fungsi hiburan (entertainment), yaitu menyediakan hiburan, pengalihan, perhatian, dan meredakan ketegangan sosial. Kelima, fungsi mobilisasi (mobilization), yaitu mengampanyekan kepada masyarakat mengenai hal-hal yang berkaitan dengan politik, perang, pembangunan, ekonomi, dan agama.

Pepatah arab mengatakan, "al-waqt ka al-saif, in lam taqtha'hu qatha'aka" (waktu itu laksana pedang, jika engkau tidak dapat menggunakannya, makai ia akan menebasmu). Tayangan televisi yang menarik pada jam belajar anakanak telah mendorong mereka yang jumlahnya ribuan bahkan jutaan bunuh

\footnotetext{
${ }^{25}$ Jalaluddin Rakhmat, Psikologi Komunikasi, (Bandung: Remaja Rosdakarya, 1999), Cet. ke-13, h. 220 .

${ }^{26}$ Lihat Little John, Theories of Human Communication, Fifth Edition, (New York: Wadsworth Publishing Company, 1996), h. 324.

27 Dennis McQuaill, Mass Communicatin Theory, Third Edition, (USA : Sage Publication, 1994), h. 79.
} 
diri terpenggal waktu di depan televisi. Hiburan memang merupakan kebutuhan pemirsa, namun menjadi problem besar ketika penyediaan kebutuhan hiburan itu mengganggu kebutuhan lain yang lebih urgen, yakni penciptaan generasi muda yang cerdas, disiplin beribadah, dan berakhlak mulia.

Program dakwah "Serambi Islami" memberi dampak positif bagi audience yang menyaksikan acara tersebut. Hal ini dapat dilihat dari rating yang menunjukkan banyak peminat. ${ }^{28}$ Hanya saja, pemilihan waktu di pagi hari dipandang kurang kondusif, sebab berbenturan dengan waktu persiapan berangkat ke tempat kerja. Karena itu, kondisi WFH saat ini dapat dimanfaatkan untuk menghadirkan program dakwah yang berkualitas dan diterima pemirsa TVRI.

Kata dakwah, berasal dari bahasa Arab, da'a-yad'u-da'watan, yang berarti: "seruan; panggilan; ajakan; undangan; permintaan". ${ }^{29}$ Kata dakwah yang terdapat di dalam al-Qu' ran, apabila dilihat dari akar katanya " $d a^{\prime} a$ ", paling tidak memiliki sepuluh arti, yaitu: menyeru (QS Ali ‘Imran/3:104); memanggil (QS alRum/30:25); do'a (QS. al-Baqarah/2:186); menganggap (QS. Maryam/19:91); mengharapkan (QS al-Furqan/25:13); meminta (QS Muhammad/47:37); keluhan (QS al-A'raf/7:5); mengadu (QS al-Qamar/54:10); menyembah (QS al-Jin/72:18); berteriak (QS al-Insyiqaq/84:11). Perbedaan makna dari akar kata $d a^{\prime} a$ menunjukkan bahwa tidak cukup memahami pengertian dakwah hanya dalam konteks bahasa.

Istilah dakwah diungkapkan al-Qu'ran dalam bentuk fi'il maupun mashdar. Al-Qu'ran menggunakan kata dakwah untuk mengajak kepada kebaikan yang disertai dengan risiko masing-masing pilihan. Di dalam al-Qu'ran, dakwah dalam arti “mengajak" memiliki dua arti yakni mengajak kepada Islam dan kebaikan,

28 Wawancara dengan Neneng Rosiati, 09 Desember 2020.

${ }^{29}$ Ahmad Warson Munawwir, Al-Munawwir; Kamus Arab-Indonesia, (Yogyakarta: Pondok Pesantren Al-Munawwir Krapyak, 1984), h. 439. 
dan mengajak ke neraka atau kejahatan. Di samping itu, ayat-ayat yang menjelaskan istilah dakwah banyak sekali dalam konteks yang berbeda. Misalnya mengajak (manusia) kepada kebaikan dan mencegah kemunkaran (QS Ali 'Imran/3:104); mengajak ke jalan Allah (QS al-Nahl/16:125); ajakan kepada din alIslam (QS al-Shaff/61:7); menyeru kepada jalan yang lurus (QS alMu'minun/23:73); orang-orang musyrik yang menyeru berhala-berhalanya agar memberi petunjuk; dan hasilnya seruan mereka tidak diperkenankan, karena berhala-berhala tersebut tetap diam (QS al-A'raf/7:193); ajakan kepada Allah dan RasulNya (QS al-Nur/24:48 dan 51); ajakan berpegang kepada kitab Allah (QS Ali 'Imran/3:23).

Berdasarkan inilah, ada yang berpendapat bahwa aktivitas dakwah dalam konteks mengajak kepada kebaikan harus disebut dengan "dakwah Islam”, sebab terdapat ajakan yang menjurus kepada kemunkaran. Namun ada pula yang menegaskan, terminologi dakwah telah maklum (dikenal) di kalangan masyarakat muslim sebagai kegiatan ajakan yang bersifat Islami. Dengan demikian, istilah dakwah sudah jelas keberadaannya, yakni aktivitas mengajak/menyeru ke jalan Allah dan RasulNya. Karenanya, segala bentuk ajakan yang tidak Islami bukanlah dakwah.

Dari pengertian tersebut dapatlah dipahami bahwa dakwah pada dasarnya mengajak; yakni menyadarkan, mengarahkan dan membimbing manusia agar berbuat sesuai dengan tuntunan ajaran Islam tanpa adanya paksaan. Dakwah merupakan suatu aktivitas mengajak kepada orang lain dalam bentuk lisan, tulisan, maupun tingkah laku, yang dilakukan secara sadar untuk mengamalkan ajaran Islam dengan berbagai metode. Tujuannya adalah untuk mengubah manusia, baik individu maupun masyarakat dari kondisi yang tidak baik kepada yang lebih baik, sehingga dapat meraih kebahagiaan hidup di dunia dan di akhirat. ${ }^{30}$

${ }^{30}$ Di dalam al-Qur'an, terdapat dua jenis pesan dakwah: Pertama, yang maknanya memanggil akal agar digunakan untuk berpikir mencari kebenaran. Allah SWT seringkali menggunakan redaksi 
Pada praktiknya, masalah pemahaman dan wawasan umat Islam tentang dakwah menjadi problem dakwah itu sendiri. ${ }^{31}$ Pertama, dakwah dipahami sebagai sebuah misi menyebarkan agama, yakni mengajak orang-orang yang mempercayainya sebagai tugas suci yang wajib dilakukan. ${ }^{32}$ Pemahaman semacam ini diungkapkan oleh Max Muller, bahwa semangat memperjuangkan kebenaran itulah yang tak kunjung padam dari jiwa para penganutnya, sehingga kebenaran itu terwujud dalam pikiran, kata-kata dan perbuatan, sampai berhasil menanamkan nilai kebenaran tersebut ke dalam jiwa setiap orang, sehingga apa yang diyakini sebagai kebenaran diterima oleh seluruh manusia. ${ }^{33}$ Pendapat Muller ini menggiring pemaknaan dakwah menjadi sempit, yakni mengarah kepada misi atau tugas mengubah keyakinan dengan berbagai cara agar mendapat banyak pengikut. Kedua, dakwah dipahami sebagai kegiatan tabligh yang identik dengan ritualitas keagamaan dalam bentuk ceramah dan pengajianpengajian majelis taklim. Pemahaman ini membuat aktifitas dakwah hanya terlihat ketika peringatan hari-hari besar Islam dan tabligh-tabligh akbar.

Terminologi dakwah sebagai sebuah kegiatan mengajak dalam bentuk tabligh diungkapkan oleh beberapa pemikir dakwah seperti Muhammad Abu alFath al-Bayanuniy dan Syekh 'Ali Mahfuzh. ${ }^{34}$ Meskipun kedua pemikir tersebut

"afala ta'qilun" (tidakkah engkau memikirkan). Kedua, pesan yang maknanya menghimbau rasa serta hati agar tersentuh dan dapat memahami kebenaran. Hal ini diungkapkan al-Qur'an dengan redaksi "afala tash'urun (tidakkah engkau merasakan). Lihat Ahmad Atabik, "Konsep Komunikasi Dakwah Persuasif Dalam Perspektif Al-Qur'an, At-Tabsyir, Jurnal Komunikasi Penyiaran Islam, Volume 2, Nomor 2, Juli-Desember 2014, h. 125.

${ }^{31}$ Problem dakwah secara garis besar dapat diidentifikasi ke dalam dua faktor, yaitu internal dan eksternal. Faktor internal berkaitan dengan soal wawasan dan pelaksanaan dakwah di kalangan umat Islam. Sedangkan faktor eksternal berkaitan dengan upaya-upaya dari kelompok tertentu yang memusuhi Islam. Lihat Muhammad Abu al-Fath al-Bayanuniy, Al-Madkhal Ila 'Ilmi al-Da'wah, (Beirut: Muassasah al-Risalah, 1442 H/1993 M), Cet. ke-2, h. 352-353.

${ }^{32}$ Sifat misionar agama ini dapat dilihat dalam kitab suci agama kristen yang terdapat pernyataan" Pergilah kamu ke seluruh bumi, beritakanlah injil itu kepada sekalian alam' (Markus, 16:15), dan "sebab itu pergilah kamu, jadikanlah sekalian bangsa itu muridku serta membaptiskan dia dengan nama Bapa, Anak dan Ruhul Kudus" (Matius/28:9). Dalam kitab suci al-Qur'an juga dinyatakan: "Hai Rasul, sampaikanlah apa yang diturunkan kepadamu dari Tuhanmu" (QS. AlMaidah/5:67).

${ }^{33}$ Thomas W. Arnold, The Preaching of Islam (Jakarta: Widjaya,1981), Cet. ke-2, h. 1.

${ }^{34}$ Muhammad Abu al-Fath\} al-Bayanuniy merumuskan pengertian dakwah sebagai berikut: 
Program Dakwah 'Serambi Islami' di TVRI Perspektif Audience And Users

memberikan definisi dakwah yang sangat identik dengan kegiatan tabligh (ceramah), namun penekanan makna dakwah tidak hanya dibatasi pada makna tabligh, tetapi juga bagaimana pesan-pesan yang disampaikan dapat direalisasikan dalam kehidupan.

Pemikir sekaligus praktisi dakwah Sayyid Quthb menyatakan bahwa dakwah adalah mengajak orang lain ke jalan Allah, bukan untuk mengikuti seseorang (da'i) atau kelompoknya. Bagi da'i, tidaklah dakwah yang dilakukan itu, kecuali menjalankan tugas dan kewajibannya kepada Allah SWT", ${ }^{35}$

Pengertian dakwah yang diungkapkan Quthb di satu sisi sejalan dengan konsep dakwah Max Muller, yaitu menekankan pada misi suci yang wajib dilaksanakan. Namun di sisi lain terdapat perbedaan yang mendasar, yakni dalam pemikiran Quthb, dakwah adalah upaya maksimal orang yang beriman untuk mewujudkan sistem (ajaran) Islam di dalam realitas kehidupan, yang meliputi: akidah, ibadah, akhlak, syariah, muamalah (ekonomi, politik serta hubungan antar negara) sesuai prinsip dan asas Islam. Ini berarti, dakwah menjadi kewajiban yang harus ditunaikan oleh seluruh umat Islam.

Ismail Raji al-Faruqi menyebutkan bahwa urgensi dari seluruh aktivitas dakwah baik secara teori maupun praktik, dimulai dari bagaimana cara seorang muslim memandang hakikat dirinya sebagai seorang yang memiliki kewajiban menyeru semua manusia kepada kehidupan yang tunduk hanya kepada Allah dan kepada Islam sebagai aturan dan prinsip hidup. ${ }^{36}$

\footnotetext{
"Menyampaikan dan mengajarkan Islam kepada manusia untuk diterapkan dalam realitas"

تبليغ الإسلام للناس وتعليمه وتطبيقه فى واقع الحيباة حث الناس على الخير والهدى و الأمر بالمعروف و النهي عن المنكر ليفوزوا بسعادة العاجل و الأجل "Mengajak manusia kepada kebaikan dan petunjuk, menyuruh berbuat baik serta mencegah berbuat munkar untuk mencapai kebahagiaan dunia dan akhirat". Lihat M. Yunan Yusuf dalam Munzier Suparta, Harjani Hefni (Ed.), Metode Dakwah, (Jakarta: Kencana, 2003), Cet. ke-1, h. xv.

35Sayyid Quthb, Tafsir fi Zhilal al-Qur'an, (Kairo: Dar al-Shuruq, 1992), Jilid 4, Cet. ke-17, h. 22012202.

36Ismail R. Al-Faruqi, Louis Lamya Al-Faruqi, The Cultural Atlas of Islam, (Macmillan Publishing Company, New York, Amerika Serikat, 1986), h. 217.
} 
Karena itu, yang dituntut dari setiap muslim adalah berdakwah sebatas kemampuannya, walaupun hanya satu ayat. Sesuai keterangan sebuah hadis: "sampaikanlah dari ajaranku walau hanya satu ayat" (Riwayat Bukhari). ${ }^{37}$ Bahkan dalam al-Qur'an ditegaskan: “Allah tidak membebani seseorang melainkan sesuai dengan kesanggupannya... " (QS al-Baqarah/2:286).

Hal ini diperkuat dengan penjelasan sebuah hadis:

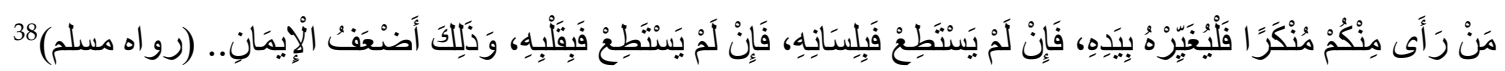
“Barangsiapa di antara kamu melihat kemungkaran, hendaklah ia mengubah dengan tangannya. Bila ia tidak mampu melakukannya, maka hendaklah mengubah dengan lisannya. Bila ia tidak mampu juga, maka hendaklah melakukan penentangan kemungkaran dengan hatinya, dan itu selemahlemahnya iman" (Riwayat Muslim. Nomor 49).

Hadis di atas menguatkan pernyataan QS Ali ‘Imran /3:110 bahwa dakwah dalam arti yang luas merupakan kewajiban yang harus dipikul oleh setiap muslim/muslimah. Minimal komitmen sikap inklusif dan universal terhadap seluruh manusia, menolak kemungkaran dengan hatinya, jika tidak bisa melakukan amar ma'ruf-nahi munkar melalui power fisik dan lisan. Karena penolakan kemungkaran dengan hati itu adalah tempat bertahan yang minimal dan benteng penghabisan. Konsekuensi logisnya, jika hati sebagai tempat bertahan yang terakhir sudah ditinggalkan, maka selemah-lemahnya iman itupun sudah lenyap.

${ }^{37}$ Hadis ini dari sahabat Abdullah bin 'Amr bin al-Ash bin Wa'il bin Hasyim bin Su'aid bin Sa'ad bin Sahm al-Sahmiy. Ia adalah salah satu di antara al-'Abadilah (para sahabat yang bernama Abdullah, seperti 'Abdullah Ibn Umar, 'Abdullah ibn Abbas, dan sebagainya) yang pertama kali memeluk Islam, dan seorang di antara fuqaha' dari kalangan sahabat. Ia meninggal pada bulan Dzulhijjah pada peperangan al-Harrah, atau menurut pendapat yang lebih kuat, ia meninggal di Tha'if.

${ }^{38} \mathrm{Abu}$ al Husain Muslim bin al-Hajjaj al-Qusyairi al-Naisaburi, Shahih Muslim, (Beirut: Dar alIhya' al Turats al-'Arabi, 261 H), Jilid 1, Nomor 49, h. 69. 


\section{Pesan Dakwah}

Pesan dakwah yang disampaikan dalam program "Serambi Islami" di TVRI adalah ajaran Islam yang meliputi: kehidupan, manusia, harta benda, ilmu pengetahuan, dan akidah. Dari sini dapat dirumuskan lima pokok pesan dakwah sebagai berikut:

a. Masalah kehidupan, yaitu dakwah memperkenalkan dua jenis kehidupan, yakni kehidupan duniawi dan kehidupan akhirat yang memiliki sifat kekal abadi $^{39}$

b. Masalah manusia. Pesan dakwah ini adalah menempatkan manusia pada posisi yang mulia yang harus dilindungi secara penuh. ${ }^{40}$ Dalam hal ini manusia ditempatkan pada dua status, yaitu sebagai: 1) ma'sum, yakni memiliki hak hidup, hak memiliki, hak berketurunan, hak berpikir sehat, dan hak untuk menganut sebuah keyakinan imani, 2) mukallaf, yaitu diberi kehormatan yang mencakup: a) pengenalan yang benar dan pengabdian yang tulus kepada Allah SWT, ${ }^{41}$ b) pemeliharaan dan pengembangan dirinya dalam perilaku dan perangai yang luhur, c) memelihara hubungan yang baik, yang damai, dan rukun dengan lingkungan;

c. Masalah harta benda. Pesan dakwah dalam bentuk ini, lebih pada penggunaan harta benda untuk kehidupan manusia dan kemaslahatan umat. Ada hak tertentu yang harus diberikan kepada orang yang berhak untuk menerimanya;

d. Masalah ilmu pengetahuan. Dakwah sangat mengutamakan pentingnya pengembangan ilmu pengetahuan. Pesan yang berupa ilmu pengetahuan disampaikan melalui tiga jalur ilmu, yaitu: 1) mengenal tulisan dan membaca, 2) penalaran dalam penelitian dan rahasia-rahasia alam, 3) penggambaran di bumi seperti study tour atau ekspedisi ilmiah;

${ }^{39}$ QS al-Baqarah/2:2001.

${ }^{40}$ Wahyu Ilaihi, Komunikasi Dakwah, (Bandung: PT Remaja Rosdakarya, 2010), h. 102-103.

${ }^{41}$ QS al-Dzariyat/51:56. 
e. Masalah akidah dalam pesan utama dakwah, memiliki ciri-ciri yang membedakan dengan kepercayaan lain, yaitu: 1) keterbukaan melalui kesaksian (syahadat). Dengan demikian, seorang muslim selalu jelas identitasnya dan bersedia mengakui identitas keagamaan orang lain, 2) cakrawala yang luas dengan memperkenalkan bahwa Allah SWT adalah Tuhan alam semesta, bukan Tuhan kelompok atau bangsa tertentu, 3) kejelasan dan kesederhanaan. Seluruh ajaran akidah, baik soal ketuhanan, kerasulan, ataupun alam ghaib sangat mudah untuk dipahami, 4) ketuhanan antara iman dan Islam, atau antara iman dan perbuatan.

Dari penjelasan di atas, yang terpenting adalah konteks penyampaian ayatayat Allah SWT, berangkat dari persoalan yang dihadapi masyarakat. Perasaan empati ini akan membuat dakwah menjadi lebih efektif. Rasa empati juga akan membuat juru dakwah (da'i) dapat memahami situasi yang sedang dihadapi objek dakwahnya (mad'u). Pemahaman seperti ini sangatlah penting, supaya materi dakwah yang disampaikan dapat benar-benar menjawab persoalan yang tengah dihadapi publik.

Dakwah yang disampaikan tidak cukup hanya dimengerti, tetapi juga harus dirasakan manfaatnya. Dalam teori uses (kegunaan), audience akan menerima pesan, ketika dipandang bermanfaat atau berguna. Aktivitas dakwah yang memberi manfaat kepada objek dakwah (mad'u), akan diterima dan diminati. Karena itu, Rasulullah saw menyatakan, "sebaik-baik manusia adalah yang paling bermanfaat untuk sesamanya." Manfaat dalam hal ini sangat erat dengan keberhasilan komunikasi dakwah. Kata komunikasi berasal dari bahasa latin communico, yang berarti "berbagi," yaitu sebuah proses sosial yang mengacu pada tindakan menyampaikan, bertukar ide, pengetahuan, atau informasi. ${ }^{42}$ Pendapat senada disebutkan Muis bahwa secara etimologis, komunikasi berasal dari bahasa latin, yakni communicare yang berarti berbicara, menyampaikan pesan, informasi,

${ }^{42}$ Hamid Mowlana, "Theoretical perspectives on Islam and communication," China Media Research , 3 (4), 2007, h. 23-33. 
perasaan, gagasan, dan pendapat yang dilakukan oleh seseorang kepada yang lain dengan mengharapkan jawaban, tanggapan atau arus balik (feedback). ${ }^{43}$

Beberapa pakar memberikan definisi yang berbeda-beda tentang komunikasi, ada yang memfokuskan pada unsur penyampaian, unsur mempengaruhi, dan unsur kontrol sosial. ${ }^{44}$ Berelson dan Steinner, mendefinisikan komunikasi sebagai "penyampaian, informasi, ide, emosi, keterampilan, dan seterusnya, melalui penggunaan symbol kata, gambar, angka, grafik, dan lainlain". ${ }^{45}$ Komunikasi dalam pengertian ini, lebih difokuskan pada unsur penyampaian, dan definisi yang disampaikan berelson dan Steinner adalah yang paling banyak dipergunakan. Sementara Shannon dan Weaver, menambahkan definisi tersebut dengan "mencakup semua prosedur melalui pikiran seseorang yang dapat memengaruhi orang lainnya". ${ }^{46}$ Definisi ini lebih menekankan pada unsur memengaruhi.

Unsur kontrol sosial, memberikan makna lain dari definisi komunikasi yang diungkapkan oleh Shachter yang menulis bahwa, "komunikasi merupakan mekanisme untuk melaksanakan kekuasaan". Kontrol sosial di mana seseorang berusaha mempengaruhi perilaku, keyakinan, sikap, dan seterusnya dari orang lain dalam suatu suasana sosial. ${ }^{47}$ Pendapat shachter, sejalan dengan pengertian komunikasi yang diungkapkan oleh Onong Uchjana Effendy, yakni "suatu proses penyampaian pesan oleh seseorang kepada orang lain untuk memberitahu atau mengubah sikap, pendapat, atau perilaku, baik langsung secara lisan, maupun tidak langsung melalui media". ${ }^{48}$ Pembicaraan mengenai pengertian komunikasi

\footnotetext{
${ }^{43}$ A. Muis, Komunikasi Islami, (Bandung: PT Remaja Rosdakarya, 2001), Cet. ke-1, h. 36.

${ }^{44}$ Andi Faisal Bakti, Communication and Family Planning in Islam Indonesia: South Sulawesi Muslim Perception of a Blobal Develompment Program, (Leiden-Jakarta: INIS, 2004), h. 39-40.

${ }^{45}$ Bernard Berelson, dan Gray Steinner, Human Behavior, (New York: Harcourt, Brace Jovanivich Inc, 1964) dalam B Aubrey Fisher, Teori-teori Komunikasi, (Bandung: Remaja Rosdakarya, 1978), h. 10.

${ }^{46}$ Claude Shannon dan Warren Weaver, The Mathemmatical Theory of Communication, (Urbana: University of Illinois Press, 1949), h. 10.

${ }^{47}$ Stanley Schachter, "Deviation, Rejection, and Communication," Journal of Abnormal and Social Psychology, 46, h.190-270.

${ }^{48}$ Onong Uchjana Effendy, Dinamika Komunikasi, (Bandung: PT. Remaja Rosdakarya, 2008), Cet. ke-7, h. 5.
} 
tidak dapat dilepaskan dari pemikiran Harold Lasswell. Ia mengatakan bahwa cara yang paling nyaman untuk menggambarkan komunikasi adalah dengan menjawab pertanyaan-pertanyaan tentang, siapa? Apa yang dikatakan? Melalui saluran apa? Kepada siapa? Dengan efek apa? ${ }^{49}$ Atau yang dikenal dengan istilah 5W $1 \mathrm{H}$.

Jika diuraikan secara sederhana, maka dapat diartikan bahwa komunikasi menurut Lasswell harus mencakup lima unsur, yakni orang yang meyampaikan pesan (komunikator), pesan yang disampaikan (message), alat yang digunakan untuk menyampaikan pesan (media), orang yang menerima pesan (komunikan), dan bagaimana efek dari pesan yang disampaikan. Definisi ini menjadi sangat populer dalam pembahasan ilmu komunikasi karena memberikan gambaran yang cukup lengkap tentang proses komunikasi.

Melalui penjelasan Lasswel ini, dapat diambil pengertian bahwa, komunikasi adalah proses yang resiprokal dan berkelanjutan dengan semua pihak yang terlibat saling berkaitan dengan menciptakan makna bersama. Dengan demikian, komunikasi lebih tepatnya didefinisikan sebagai proses menciptakan makna bersama. ${ }^{50}$ Oleh karena itulah penting ditekankan bahwa unsur pemberi, penerima, media dan efek sebuah pesan menjadi faktor yang penting dalam proses komunikasi.

Dari beberapa definisi komunikasi yang telah diungkapkan oleh beberapa pakar di atas, pendapat Alo Liliweri dalam bukunya "Komunikasi Serba Ada Serba Makna" yang mengutip pendapat Ruben dan Stewart cukup mewakili, yakni, "Komunikasi merupakan sesuatu yang sangat esensial bagi individu, relasi, kelompok, organisasi dan masyarakat, ia merupakan garis yang menghubungkan antara manusia dan dunia, komunikasi sebagai sarana manusia

\footnotetext{
${ }^{49}$ Harold Lasswell dalam Stanley J. Baran, Pengantar Komunikasi Massa, Melek Media dan Budaya, (Jakarta: Erlangga, 2012), Jilid 1, Edisi 5, h. 5.

50 Stanley J. Baran, Pengantar Komunikasi Massa, Melek Media dan Budaya, (Jakarta: Erlangga, 2012), Jilid 1, Edisi 5, h. 6.
} 
untuk mengekspresikan diri dan memengaruhi orang lain". Karena itu, jika manusia tidak berkomunikasi, maka ia tidak dapat menciptakan dan memelihara relasi dengan sesama dalam kelompok, organisasi dan masyarakat; komunikasi memungkinkan manusia mengoordinasikan semua kebutuhannya dengan dan bersama orang lain. ${ }^{51}$

Berdasarkan hal tersebut, dapat dikatakan bahwa komunikasi merupakan pendorong proses sosial, yang ditentukan oleh akumulasi, pertukaran dan penyebaran pengetahuan. Tanpa komunikasi, manusia akan tetap hidup primitif, statis, terjebak dalam perilaku instingtif dan tidak banyak berbeda dari hewan. Berdasarkan sifat-sifatnya, komunikasi terbagi mennjadi dua jenis; komunikasi tatap muka (face to face communication) dan komunikasi bermedia (mediated communication). Komunikasi tatap muka dipergunakan apabila kita mengharapkan efek perubahan tingkah laku (behavior change) dari komunikan. Di sinilah terlihat fungsi feedback langsung dan biasa digunakan sebagai komunikasi yang persuasif. Sedangkan komunikasi bermedia (public media dan mass media) pada umumnya digunakan untuk komunikasi informatif, karena tidak begitu banyak diharapkan mampu mengubah tingkah laku, lebih-lebih media massa. ${ }^{52}$

Secara lebih detail maksud dari komunikasi persuasif adalah "melakukan upaya untuk mengubah sikap, pendapat dan perilaku seseorang melalui cara-cara yang luwes, manusiawi dan halus, dengan akibat munculnya kesadaran, kerelaan, dan perasaan senang serta adanya keinginan untuk bertindak sesuai dengan yang dikatakan persuader/komunikator." 53 Pada praktiknya komunikasi semacam ini sering digunakan dalam upaya propaganda ${ }^{54}$ dan kampanye sebagai

${ }^{51}$ Ruben \& Stewart, 1988, dalam Alo Liliweri, Komunikasi Serba Ada Serba Makna, (Jakarta: Kencana, 2011), cet. ke-1, h. 35.

52 Onong Uchjana Effendy, Dinamika Komunikasi, h. $32 .$.

${ }^{53}$ Soleh Soemirat, H. Hidayat Satari, Asep Suryana, Komunikasi persuasif, (Jakarta: Universitas terbuka, 2007), Cet. ke-5, h. 26.

54 Propaganda berasal dari bahasa Yunani, yaitu "propagare" yang artinya menyebarkan atau meluaskan. Misalnya dikatakan: Plato telah melaksanakan propaganda, artinya menyiarkan ide- 
upaya memengaruhi dan mencari dukungan sebanyak-banyaknya dari masyarakat. Begitu pula dengan kegiatan khutbah/ceramah para da'i sebagai upaya untuk menanamkan nilai-nilai agama dan kesadaran kepada objek dakwah (mad'u). Dalam hal ini, teknik memengaruhi sebagai bagian dari unsur komunikasi terlihat jelas dari cara-cara komunikasi yang dilakukan.

Komunikasi Massa ialah penyebaran pesan dengan menggunakan media yang ditujukan kepada massa yang abstrak, yakni sejumlah orang yang tidak tampak oleh si penyampai pesan. Seperti pembaca surat kabar, pendengar radio, penonton televisi, film dan lain-lain. Komunikasi massa ditujukan kepada khalayak yang jumlahnya relatif besar. Adapun fungsi dari komunikasi massa adalah menyiarkan informasi (to inform), mendidik (to educate), dan menghibur (to entertain) ${ }^{55}$ Sebagian besar teori komunikasi berasal dari pada Barat dan mengikut perpektif Barat, sehingga nilai-nilai yang dikembangkan dalam teori komunikasi tidak didasarkan pada konteks sosial, budaya dan agama sebuah masyarakat. ${ }^{56}$ Hamid Maulana menganggap bahwa Komunikasi Islam adalah respons Islam terhadap komunikasi model Barat. Komunikasi yang selaras dengan nilai-nilai budaya dan sejarah dunia Islam. Pusat analisisnya adalah gagasan tabligh (propagasi). ${ }^{57}$ Pada komunikasi Islam, landasan teori dan filosofinya tentulah al-

idenya yang terkenal melalui pembujukan lewat syiar dan kata-kata sasteranya. Propaganda sifatnya umum, dapat digunakan untuk maksud-maksud baik atau untuk maksud-maksud buruk. Lihat Toha Yahya Omar, Ilmu Da'wah (Jakarta: Widjaya, 1985), Cet. ke-4, 2. Istilah Propaganda adalah konsep Barat dan digunakan untuk pertama kalinya oleh sebuah komite Cardinals (Didirikan pada 1622 oleh Paus Gregorius) dari Romawi Gereja Katolik memiliki perawatan dan pengawasan misi asing. Propaganda berasal dari bahasa Latin propagare dan aslinya berarti menyebarkan Injil dan mendirikan Gereja di negara non-Kristen. Sejak Perang Dunia I, yang definisinya telah berkembang berkonotasi alat persuasi dan manipulasi individu dan perilaku kolektif. Lihat Hamid Mowlana, "Theoretical Perspectives on Islam and Communication", China Media Research, 3(4), 2007, 26.

${ }_{55}$ Onong Uchjana Effendy, Dinamika Komunikasi, h. 32.

${ }^{56}$ Sofia Hayati Yusoff, Western And Islamic Communication Model: A Comparative Analysis On A Theory Application, http://abqarijournal.usim.edu.my/current-issue/volume-7-2016.

${ }^{57}$ Khiabany, G. De-westernizing media theory, or reverse orientalism; 'Islamic communication' as theorized by Hamid Mowlana. Media Culture \& Society, 2003 ,25, h. 415-422. 
Qur'an dan hadis. Dengan sendirinya, komunikasi Islam terikat pada pesan khusus, yakni dakwah. ${ }^{58}$

Dalam kajian ilmu komunikasi Islam (Islamic Communication) etika dakwah menjadi bagian yang tidak dapat dipisahkan. Kontribusi dakwah dalam komunikasi dirumuskan oleh Andi Faisal Bakti dengan istilah tabligh information (SMCR), yakni sender (pengirim), message (pesan), channel (saluran/media), dan receiver (penerima). Untuk melihat hasil dari proses SMCR, Andi menambahkan dengan effect (dampak), sehingga terjadi convergence (titik temu) yang menghasilkan active reception (penerimaan aktif) yang kemudian disingkat dengan (SMCR-E-Convergence-AR). ${ }^{59}$

Masih menurut Andi, model ini bukannya tanpa dasar dalam sains. Studi komunikasi setelah WW II mengakui model SMCR, di mana pengirim, pesan, saluran, dan penerima memiliki hubungan linier. Akibatnya, model E (efek) diperkenalkan, dengan alasan bahwa hasilnya, atau apa yang diterima, lebih penting dari pada apa yang dikatakan oleh pengirim menggunakan media massa. Dalam model ini penerima dianggap pasif. Spesialis komunikasi datang dengan menggunakan model penerima aktif, dalam upaya untuk memperbaiki model SMCR dan E. Sementara mereka yang memperkenalkan model-model ini percaya bahwa, dengan menggunakan saluran yang baik, pengirim akan membawa pesan langsung ke penerima, dan yang terakhir akan secara otomatis memahami apa yang diinginkan pengirim untuk dipahami. Model penerima aktif (active reception) berpendapat bahwa selama penerima tetap dianggap pasif, tidak ada pesan yang dapat disampaikan. Namun menurut teori ini, tidak ada penerima yang pasif.

58 A. Muis, Komunikasi Islam, h. 66.

59 Andi Faisal Bakti, "The Contribution of Dakwah to Communication Studies: Risale-i Nur Collection Perspective," diakses melalui http://www.risaleinur.com/studies/139conferences/2010/4127-the-contribution-of-dakwah-to-communication-studies.html, 28 Juni 2019. 
Bahkan penerima lebih sering mengerti, dan melampaui apa yang dimaksud oleh pengirim. ${ }^{60}$

\section{Audience Dakwah}

Kesuksesan sebuah stasiun televisi dapat diukur dari seberapa banyak audience dari stasiun televisi tersebut. Tidak ada televisi yang bisa bertahan tanpa adanya audience. Hubungan televisi dengan audience sangat kuat, di mana apabila televisi memiliki audience yang cukup banyak, maka para pengiklan akan banyak berdatangan. Hubungan yang kuat itu dapat terjadi apabila televisi tersebut dapat memuaskan kebutuhan dari audiencenya, tetapi apabila televisi tersebut tidak dapat memuaskan kebutuhan dari audiencenya, maka audience tersebut dapat memindahkan channel ke televisi lain. ${ }^{61}$

Audience berpengaruh dalam penentuan program, karena audience sebagai konsumen yang keinginan dan kebutuhannya diwujudkan dalam bentuk program acara. Salah satu wujud mengakomodasi keinginan masyarakat adalah dengan dibuatnya program yang dekat dengan kehidupan mereka sehari-hari dan sesuai dengan keinginan mereka. Menurut J. David Lewis, pengaruh audien dalam keputusan perencanaan adalah dalam bentuk pemberian umpan balik (feedback) secara langsung dan laporan peringkat (rating) program. ${ }^{62} \mathrm{Hal}$ tersebut juga terjadi di TVRI, tidak dapat dipungkiri bahwa sebagai institusi bisnis, TVRI memerlukan audience untuk mempertahankan program tersebut serta menarik minat pengiklan. Program yang dianggap sesuai dengan apa yang diinginkan oleh audien otomatis akan membuat program itu ditonton oleh banyak orang, yang berakibat tingginya jumlah rating, sehingga akan mengundang minat

60 Andi Faisal Bakti, "The Contribution of Dakwah to Communication Studies: Risale-i Nur Collection Perspective," diakses melalui http://www.risaleinur.com/studies/139conferences/2010/4127-the-contribution-of-dakwah-to-communication-studies.html, 28 Juni 2019.

61 Perbinossoff, P., Gross, B., \& Gross, L. S. 2005. Programming for TV, Radio, and the Internet: Strategy, Development, and Evaluation. Oxford: Elsevier Focal Press, h. 134.

${ }^{62}$ Morissan, Jurnalistik Televisi Mutakhir, (Jakarta: M. A Kencana, 2008), h. 245. 
pengiklan untuk mengiklankan produk pada program tersebut. Sama halnya dengan yang dijelaskan Peter Pringle, bahwa program yang gagal menarik pendengar atau pemirsa, atau gagal untuk memuaskan kebutuhan mereka, berada dalam posisi berbahaya. Begitu pula keuangan stasiun yang bersangkutan. ${ }^{63}$

Audience dalam program dakwah serambi Islami TVRI adalah pemirsa televisi yang menonton acara tersebut. Dalam konteks dakwah, audience di sini dikategorikan sebagai mad'u (objek dakwah). Dengan demikian, sasaran yang menjadi prioritas program dakwah serambi Islami adalah kalangan usia dewasa. Acara ini menyuguhkan kajian keislaman dalam bentuk ceramah dan dialog interaktif.

\section{Kesimpulan}

Secara substantif, dakwah adalah ajakan yang bersifat Islami. Untuk menyampaikan pesan-pesan dakwah, diperlukan media yang efektif. Televisi merupakan media massa yang strategis sebagai sarana dakwah. Media ini sangat populer di tengah masyarakat yang dapat menjangkau audience dan pengguna hingga ke pelosok. Penyajian materi-materi dakwah di televisi yang berbobot dan menarik menjadi bagian penting, sehingga diminati pemirsa sebagai objek dakwah (mad'u).

Fakta empiris menunjukkan bahwa tayangan televisi yang kontennya memuat hiburan dan iklan-iklan lebih dominan dibandingkan dengan pesan-pesan dakwah. Hal ini terjadi, karena tayangan hiburan dan iklan lebih menarik serta diminati oleh pemirsa televisi dibandingkan dengan ceramah para da'i. Konsekuensinya, sekularisme dan budaya hedonis akan mereduksi nilai-nilai

${ }^{63}$ Morissan, Jurnalistik Televisi Mutakhir, h. 245. 
agama. Keberadaan televisi sebagai produk teknologi telah menjadi produsen kebudayaan yang berimplikasi terhadap perilaku masyarakat.

Televisi Republik Indonesia (TVRI) merupakan pelopor industri pertelevisian di Indonesia. TVRI tercipta karena adanya kehendak rakyat dan pemerintah Republik Indonesia. "Serambi Islami" adalah salah satu program dakwah TVRI yang disiarkan setiap hari, mulai pukul 4.30 hingga pukul 06 pagi. Materi dalam program dakwah "Serambi Islami" di TVRI adalah keislaman yang bersifat tematik dan kekinian. Pesan-pesan dakwah melalui program ini memberikan civil efek bagi audience pengguna televisi. Banyak respons audience yang memandang bahwa acara tersebut sangat bermanfaat, namun belum memuaskan. Waktu tayang acara dan minimnya publikasi menjadi sorotan audience, padahal TVRI seharusnya dapat menyajikan tayangan yang sesuai kebutuhan audience sebagai objek dakwah (mad'u).

\section{Saran}

Saran dari penelitian ini adalah:

a. Komisi Penyiaran Indonesia (KPI) hendaknya selektif dan kritis terhadap tayangan-tayangan televisi, sehingga kontennya sejalan dengan misi televisi sebagai media informasi, pendidikan, dan hiburan.

b. Para da'i harus memanfaatkan televisi sebagai media dakwah dengan menyajikan pesan-pesan dakwah yang menarik, konstruktif, dan solutif.

c. TVRI sebagai televisi pemerintah harus kompetitif dengan televisi-televisi swasta, khususnya menempatkan jam tayang acara-acara keagamaan. 


\section{Daftar Pustaka}

Atabik, Ahmad, “Konsep Komunikasi Dakwah Persuasif Dalam Perspektif AlQur'an," At-Tabsyir, Jurnal Komunikasi Penyiaran Islam, Volume 2, Nomor 2, JuliDesember 2014.

Bakti, Andi Faisal, Communications and Family Planning in Islam in Indonesia: South SulawesiMuslim Perceptions of a Global Development Program, Leiden-Jakarta: INIS, 2004.

_ "The Contribution of Dakwah to Communication Studies: Risale-i Nur Collection Perspective," diakses melalui http://www.risaleinur.com/studies/139-conferences/2010/4127-thecontribution-of-dakwah-to-communication-studies.html, 28 Juni 2019.

Baran,Stanley J., Pengantar Komunikasi Massa, Melek Media dan Budaya, Jakarta: Erlangga, 2012, Jilid 1, Edisi 5.

Bayanuniy, Muhammad Abu al-Fath al, Al-Madkhal Ila 'Ilmi al-Da'wah, Beirut: Muassasah al-Risalah, 1442 H/1993 M, Cet. ke-2.

Berelson, Bernard, dan Gray Steinner, Human Behavior, New York: Harcourt, Brace Jovanivich Inc, 1964 dalam B Aubrey Fisher, Teori-teori Komunikasi, Bandung: Remaja Rosdakarya, 1978.

Branston, Gill, Roy Stafford, The Media Students's Book, London and New York: Routledge, 2010.

Bungin, M. Burhan, Penelitian Kualitatif, Komunikasi, ekonomi, kebijakan public dan Ilmu Sosial lainnya. Jakarta: Kencana, 2011.

Effendy, Onong Uchjana, Dinamika Komunikasi, Bandung: PT. Remaja Rosdakarya, 2008. 
Elihu Katz, Jay Blumler dan Michael Gurevitch, “Uses Mass and Communication by the Individual," dalam Stephen W. Littlejohn, Karen A. Foss, Teori Komunikasi , Theories of Human Communication, Jakarta: Salemba Humanika. 2009.

Faruqi, Ismail R. al, Louis Lamya Al-Faruqi, The Cultural Atlas of Islam, Macmillan Publishing Company, New York, Amerika Serikat, 1986

Firiana, Dewi Karina, Sejarah TVRI, Laporan Kuliah Kerja Profesi, Fakultas Seni Rupa Dan Desain Institut Seni Indonesia Surakarta, 2016.

G., Khiabany, De-westernizing media theory, or reverse orientalism; 'Islamic communication' as theorized by Hamid Mowlana. Media Culture E Society, 2003.

https://kabar24.bisnis.com/read/20170724/79/674521/ini-nominasi-program-televisiterbaik-selama-ramadan-2017, diakses 20 Desember 2020.

Ilaihi,Wahyu, Komunikasi Dakwah, Bandung: PT Remaja Rosdakarya, 2010.

John, Little, Theories of Human Communication, Fifth Edition, New York: Wadsworth Publishing Company, 1996.

Kusnawan, Aep, “Tabligh Melalui Televisi,” dalam Aep Kusnawan, et.al., Komunikasi Penyiaran Islam, (Bandung: Benang Merah Press, 2004), Cet. ke-1.

Lasswell, Harold dalam Stanley J. Baran, Pengantar Komunikasi Massa, Melek Media dan Budaya, Jakarta: Erlangga, 2012, Jilid 1, Edisi 5.

McQuail, Dennis Mass Communication Theory, dalam Stephen W. Littlejohn, Karen A. Foss. Teori Komunikasi, Theories of Human Communication. Jakarta: Salemba Humanika, 2009.

Morissan, Jurnalistik Televisi Mutakhir, Jakarta: M. A Kencana, 2008.

Mowlana, Hamid, "Theoretical perspectives on Islam and communication," China Media Research , 3 (4), 2007. 
Program Dakwah 'Serambi Islami' di TVRI Perspektif Audience And Users

Muhtadi, Asep Saeful, Komunikasi Dakwah: Teori, Pendekatan, dan Aplikasi, Bandung: Simbiosa Rekatama Media, 2012.

Muis, A., Komunikasi Islami, Bandung: PT Remaja Rosdakarya, 2001.

Munawwir, Ahmad Warson, Al-Munawwir; Kamus Arab-Indonesia, Yogyakarta: Pondok Pesantren Al-Munawwir Krapyak, 1984.

Naisaburi, Abu al Husain Muslim bin al-Hajjaj al-Qusyairi al, Shahih Muslim, Beirut: Dar al-Ihya' al Turats al-'Arabi, 261 H, Jilid 1.

Omar, Toha Yahya, Ilmu Da'wah, Jakarta: Widjaya, 1985, Cet. ke-4.

P., Perbinossoff, Gross, B., \& Gross, L. S. 2005. Programming for TV, Radio, and the Internet: Strategy, Development, and Evaluation. Oxford: Elsevier Focal Press.

Quthb, Sayyid, Tafsir fi Zhilal al-Qur'an, Kairo: Dar al-Shuruq, 1992, Jilid 4, Cet. ke-17. Rakhmat, Jalaluddin, Psikologi Komunikasi, Bandung: Remaja Rosdakarya, 1999.

Ruben \& Stewart, 1988, dalam Alo Liliweri, Komunikasi Serba Ada Serba Makna, Jakarta: Kencana, 2011, cet. ke-1.

Ryan A., Syakur, 2010. diakses 19 November 2012. http://media.kompasiana.com/mainstream- media/2010/07/30/keberadaantvri-sebagai-televisi-publik-di-indonesia.

Schachter, Stanley, "Deviation, Rejection, and Communication," Journal of Abnormal and Social Psychology, 46.

Shannon, Claude, dan Warren Weaver, The Mathemmatical Theory of Communication, Urbana: University of Illinois Press, 1949.

Siregar, Boyke P., “Jumlah Penonton Televisi Naik 12/\% Sejak Ada PSBB dan WFH,” 13 Mei 2020, https://www.wartaekonomi.co.id/read285326/jumlah-penontontelevisi-naik-12-sejak-ada-psbb-dan-wfh, diakses 30 November 2020. 
Abdul Jalil

Soemirat, Soleh, H. Hidayat Satari, Asep Suryana, Komunikasi persuasif, Jakarta: Universitas terbuka, 2007, Cet. ke-5.

Taufik, M. Tata, Etika Komunikasi Islam, Bandung: Pustaka Setia, 2012.

Yusoff, Sofia Hayati, Western And Islamic Communication Model: A Comparative Analysis On A Theory Application, http://abqarijournal.usim.edu.my/currentissue/volume-7-2016.

Yusuf, M. Yunan dalam Munzier Suparta, Harjani Hefni (Ed.), Metode Dakwah, Jakarta: Kencana, 2003, Cet. ke-1. 